\title{
THE INCIDENCE OF UNDULANT FEVER IN CHILDREN
}

\author{
BY \\ PARKER DOOLEY, M.D. \\ Phỵsician to Kent School, Connecticut, L.S.A.
}

In the decade since Beran ${ }^{1}$ suggested that the organism responsible for contagious abortion in cattle might be pathogenic for man, innumerable cases of undulant ferer hare been diagnosed among the populations of most cirilized countries. During 1925, there were only 24 cases reported in the Cnited States, but each succeeding year thereafter an increasingly large number was reported urtil, in 1929, there were more than 1,300. Complete statistics for 1930 are not yet arailable, but it is safe to assume that there were many thousands of cases. There is every reason to believe that this increase is only apparent, and not real, as cases are being reported now which could not have been recognized before the present methods of laboratory diagnosis came into general use. In the United States at least, the number of cases reported from any given region seems to depend more on the alertness with which the physicians search for the disease than on any other factor.

With the increasing appreciation of the ubiquity and grarity of this disease, it seems adrisable for students of children's disease to try to evaluate the importance of undulant ferer among the diseases of childhood. Several theoretical considerations suggest that a higher incidence of infection prevails among children than among adults. The Brucella abortus causes a low-grade, febrile illness of a type which is frequently undiagnosed unless specific laboratory tests are made. Such low-grade ferers are so much more common in children than in adults that it would seem reasonable to expect a higher incidence of Brucella infection among children than among adults when specific tests are generally applied. Also the fact that raw milk customarily constitutes a large part of the diet of infants and little children suggests that infection may be found to be common in childhood. Despite these considerations, it has become the more or less tacit opinion of writers on undulant ferer that the disease is relatively uncommon in children. In fact. some authors have gone so far as to argue that Brucella infection is not caused by drinking milk because children seem to contract the disease so infrequently. in spite of drinking large quantities of milk.

Previous investigations.-In 1913. Larson and Sedgewick= tested 42.5 children with bone or joint disease for complement fixation. using Brucella abortus as antigen. This test was positive in 73 instances. At that time. it was not known that this organism could act as one of the human pathogens. These studies were carried out as a part of a problem relating to the transmission of antibodies through the intestinal wall. Nothing is said about the ages of the children nor about the probable source of the infection. Later these same workers ${ }^{3}$ used the 
same test on 42 new-born babies. with negative results. One babr was taken from the breast on his 7 th day, because of high ferer. the cause of which was never ascertained. He was then fed on raw cows milk. On his 21 st day his reaction was positive. Another baby, 19 months old, had a positive reaction.

In 1915 Nicoll and Pratt ${ }^{4}$ raised the question of human infection with Brucella. They performed agglutination tests on an unstated number of the inmates of a foundling asylum, including cases of marasmus, rickets: enlarged lymph nodes, and hypertrophied tonsils and adenoids, as well as on about 100 supposedly normal infants. Presumably these patients were getting raw milk. One 3 year old child had a positire reaction to $1: 100$; one child of $2 \frac{1}{2}$ years had a slightly positive reaction to $1: 10$; a 5 year old child had a positive reaction to $1: 10$. Otherwise they were all negative. These same writers also found a positive reaction in the 7 months old baby of a woman whose own serum reaction was positive in dilutions up to $1: 300$.

Hardy $\mathbf{y}^{-5}$ in summarizing all cases of undulant ferer reported in the United States up to June of 19:9, found rery few instances in children under 10 years of age. Among 354 cases in Iowa, this author noted only 4 in children under 4 years. and 8 in children between the ages of 5 and 9 years. Of these, 6 were in one family, the diagnosis being made on the basis of dried blood specimens alone. His data were collected chiefly from rarious State laboratories and consequently are not very useful in an at tempt to determine the incidence of the disease among children. Most of the blood specimens submitted to such laboratories come from rural practitioners who rarely take blood specimens from young children. Extensire bacteriological and serological studies of the blood of young children are very infrequently made sare in city clinics where, of course, the general use of pasteurized milk precludes the satisfactory study of Brucella infection. The same criticism applies to the statistics of Barne-Jones ${ }^{6}$ who found no positive agglutinations in infants under one year in some 3.700 routine blood specimens on which Brucella agglutination tests were made in the New York State laboratory. In similar specimens in the Ohio State laboratory, $\mathrm{Er}^{-}$found positive agglutination reactions in one child of 19 months, in whose family there were three persons sick with undulant ferer; and in another child of 2 years who was sick with an undiagnosed febrile illness.

In Denmark Kristensen ${ }^{8}$ has made a careful studs of 500 cases of undulant ferer and concluded that young children are not affected. Guest' carried out agglutination tests on 250 patients in the Children's Hospital of Boston, and found only one who reacted positively in dilutions up to $1: 40$. He does not state whether these children used raw or pasteurized milk. Giordano and Sensenich ${ }^{10}$ hare reported 35 cases, the youngest being 16 rears old. Hartman ${ }^{11}$ mentions an infection occurring in an 8 year old child. Bonynge ${ }^{12}$ had a case in an 11 months old infant who had been using certified milk for 9 months. Three other children in the same family had been using this milk but were not affected. King ${ }^{13}$ noted four cases in children under 6 years of age, including one 2 year old child who had what was believed to be rheumatic ferer until a chance agglutination against Brucella was found to be positive in dilutions up to 1 : 1280. This child, howerer, had been transfused with blood from two adults who had agglutinins in their sera. Simpson ${ }^{14}$ studied 90 cases of undulant ferer, nine of which occurred in children between the ages of 6 and 10 years. Kling ${ }^{15}$. in Sweden, found only one case under 10 years. a child of 8 years. Levin ${ }^{16}$ made intradermal tests on 33 children between the ages of 6 months and 14 years. Only one child, a 5 year old girl with sinusitis and mastoiditis, gave a positive skin reaction. Her serum did not contain Brucella agglutinins. Kohlbri ${ }^{17}$ saw the disease in an infant of 1 year The diagnosis was made on the basis of positire agglutination test done three days after the baby was transfused with its mother ${ }^{\prime}$ blood. Koschate ${ }^{18}$ considers childhood infection to be so rare that he reports the case of a 12 rear old boy as a curiosity. Tobler $^{19}$ has reported Brucella infection in an 8 year old girl.

Present investigations.- Since the literature on the occurrence of undulant fever in childhood is so fragmentary and inconclusive, it seems worth while to record any item which may be helpful in the understanding of it.

In the autumn of 1930 a small epidemic of undulant ferer appeared in a school community which uses raw milk from a single dairy. Several moderately severe cases of the disease occurred among the adult milk consumers. Of some 
300 adolescent boys and young adults using this milk, 41 per cent. showed serum agglutinins for Brucella abortus in dilutions over $1: 20$. Several of the cows in the dairy were found to have positive sera, and some were shedding virulent organisms in their milk. Among the consumers of this heavily infected milk, were fifteen children who had been reared on this raw milk since infancy. The age distribution of these children was as follows :-

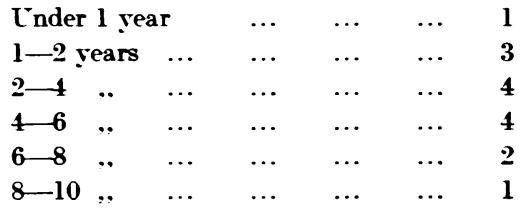

At least three agglutination tests, each with a different antigen, were done on each one of these children. The first antigen was a stock one made from four strains of Brucella of bovine origin ; the second, the so-called Huddleson antigen ; the third, a live antigen prepared from a strain of Brucella isolated from the blood of a patient ${ }^{20}$ who was infected through drinking the same raw milk which the children used. The dilutions in these agglutination tests were from $1: 10$ to $1: 640$. In not one of these children could any Brucella agglutinins be demonstrated. All of these children had been under the continuous care of the writer either since their birth, or at least for the two years preceding the testing. In that time, none of them had any illness which could possibly be suspected of being undulant fever. Although this series is very small, the results seem to justify the supposition that young children are less susceptible to infection with Brucella than are persons who have passed puberty-

In this connection, it is tempting to speculate on the apparent analogy between Brucella infection in young children and in calves. White ${ }^{21}$ states that all calves, regardless of the reaction of the dams, are born non-reactors.. When they are permitted to suck positive dams within the first $\mathbf{2 4}$ hours of life, theybecome reactors in a remarkably short time, but again become negative, almost invariably before the end of the sixth month of age. It is only after sexual maturity that definite infection is established.

\section{Summary.}

A review of the literature of undulant fever shows that little is definitely known regarding the infection in childhood.

Study of serum agglutination in young children, who had been drinking infected raw milk, suggests that ther are relatively insusceptible to the disease.

\section{REFERENCES.}

1. Bevan, L. E. W., Tr. Roy. Soc. Trop. Med. and Hyg., London, 1922, XV, 215.

2. Larson, W. B. \& Sedgewick, J. P., Am. J. Dis. Child., Chicago, 1913, VI, 326.

3. Larson, W. B. \& Sedgewick. J. P., Ibid., 1915, X, 197.

4. Nicoll, M., \& Pratt, J. S., Ibid., 1915, X, 203.

5. Hardy, A. V., et al., Nat. Inst. of Health Bull., Washington, 1930, No. 158.

6. Bayne-Jones, S., Am. J. Pub. Health, N.Y., 1930, XX, 1313. 
7. Ey, L. F., See Simpson, W. M., Ohio State Med. J., Columbus, Jan. 1931.

8. Kristensen, M., \& Holm, P., Zentralbl. Bakt., Jena, 1 Abt., 1929, CXII, 281.

9. Guest, G. M., J. Med., Cincinnati, 1929, June.

10. Giordano, A. S. \& Sensenich, R. L., J. Lab. and Clin. Med., St. Iouis, 1930, XV, 421.

11. Hartman, F. W., recorded in discussion of reference 10.

12. Bonynge, C. W., recorded in discussion of reference 10 .

13. King, M. J., New Eng. J. Med., Boston, 1929, CCI, 918.

14. Simpson, W. M., Annals Int. Med., 1930, IV, 238.

15. Kling, quoted by Löfler, W., Wurzburger Abhandl. aus dem Gesamtgebiet der Med., Leipzig, 1930, XXVI, ii, 36:

16. Levin, W., J. Lab. and Clin. Med., St. Louis, 1930, XVI, 275.

17. Kohlbry, C. O., Minn. Med., St. Paul, 1929, XII, 414.

18. Koschate, J., Jahrb. f. Kinderh., Berlin, 1930, CXXVIII, 308.

19. Tobler, Ibid., 1930, CXXIX, 72.

20. Dooley, P. New Eng. J. Med., Boston, 1931, CCIV, 759.

21. White G. C., \& Rettger, I. E., Storrs Agric. Station, Conn., 9th Rep. Bull., 1926, 137.

[EDitorial Note. So far two cases oaly i $\mathrm{f}$ Brucella infection in children have been reported in England : the first in a child of $3 \frac{1}{2}$ years by W. Broadbent, Lancet, Jan. 10th, 1931 : the second by B. Williamson and .J. Gibson in a child of $1_{1}^{x}$ years, B.M.J., May 2nd, 1931.] 